\title{
Specific dynamics in vascular endothelial growth factors (VEGF) in blood of patients with vitamin D-resistant rickets during correction of multiplanar deformities of lower limbs
}

\author{
N.S. Gvozdev, E.P. Vykhovanets, S.N. Luneva, N.V. Nakoskina, E.N. Shchurova, A.V. Popkov \\ National Ilizarov Medical Research Centre for Orthopaedics and Traumatology, Kurgan, Russian Federation
}

\begin{abstract}
Background Vitamin D-resistant rickets is a systemic disease with impaired bone remodeling that interferes with orthopaedic treatment of musculoskeletal pathologies. There is a paucity of literature focusing on the content and dynamics in vascular endothelial growth factors (VEGF) that promote the transformation of cartilage to bone. Objective Explore blood serum concentration of VEGF and VEGF-A and their receptors VEGF-R2, VEGF-R3 at stages of combined osteosynthesis in patients with vitamin D-resistant rickets during correction of multiplanar deformities of lower limbs. Material and methods The study included 24 patients with multiplanar deformities of lower limbs secondary to vitamin D-resistant rickets. Patients were treated with combined Ilizarov external fixation and intramedullary nailing using hydroxyapatite-coated wires. Serum concentration of VEGF and VEGF-A and their receptors VEGF-R2, VEGF-R3 were measured during treatment. Values obtained in the patients were compared to reference levels measured in 180 somatically healthy individuals. The quantified results were presented in a percentage of the reference values. Results Preoperative serum VEGF and VEGF-R2 concentration was significantly higher in the patients than that in normal subjects: VEGF, by $1990 \%$ (p = 0.0033); VEGF-A, by $450 \%$ $(p=0.00042)$; VEGF-R2, by $392 \%(p=0.0052)$ while preoperative serum VEGF-R3 concentration was lower by $68 \%$ $(\mathrm{p}<0.05)$ in the patients than that in subjectively healthy individuals. Surgical treatment resulted in greater increase in VEGF, VEGF-A levels with maximal concentration observed at the distraction phase. The opposite dynamics was observed with VEGF-R2 receptor. Specific dynamics was noted with VEGF-R3 receptor during surgical correction. Nearly preoperative serum concentration of VEGF-R3 was seen at the first stage showing the lowest level (21\% of the normal) during bone distraction with external fixator and regenerate formation. It was reduced by $25 \%$ of the preoperative level at the end of treatment. Conclusion Patients with vitamin D-resistant rickets demonstrated strong imbalance in serum concentrations of VEGFs and their receptors. Phase opposition dynamics in serum concentrations of VEGFs and their receptors was detected during surgical correction of multiplanar deformities of lower limbs.
\end{abstract}

Keywords: vitamin D-resistant rickets, multiplanar deformities of lower limbs, correction, Ilizarov external fixation, blood serum, vascular endothelial growth factors and their receptors

\section{INTRODUCTION}

There is a noticable increase in the incidence of genetic disorders seen in recent years [1]. Vitamin D-resistant rickets is an autosomal recessive disease caused by deficiency or impaired metabolism of vitamin D. The most widely cited estimated prevalence of vitamin D-resistant rickets is one in 20 000 pediatric population [2, 3]. Vitamin D-resistant rickets is associated with impaired renal tubular reabsorption of phosphate with consequent defective bone mineralization $[4,5]$. Patients suffering from the disease have altered bone morphology [6, 7]. Hyperosteoidosis, coarse trabecular pattern, widelymeshed structures and cystic degeneration are typically observed seen in the metaphysis. The 2-to-3-fold decrease in calcium is noted in the patients [8].

Many patients with vitamin D-resistant rickets demonstrate significant lower limb deformity (63 \%) [9] with greater incidence of mutiplanar cases $[6,10,11]$.
Although weight-bearing the patients used to maintain is inconsiderable children develop bowed legs that require surgical correction for degenerative hip and knee joints.

Vitamin D-resistant rickets is a hereditary systemic disease characterized by impaired bone remodeling that intereferes with orthopaedic treatment of musculoskeletal pathology and results in delayed bone consolidation. Local and systemic growth factors (GF) are known to be involved in the process of bone remodeling [12]. Physiologically, vascular endothelial growth factors (VEGF) induces new blood vessel formation during embryonic development [13, 14], regulates reparative angiogenesis $[15,16]$, promotes bone formation in ontogenesis and transformation of cartilage to bone [17] during distractional bone regeneration [18]. However, dynamics of VEGF in patients with vitamin D-resistant rickets who undergo surgical correction of multiplanar

[D. Gozdev N.S., Vykhovanets E.P., Luneva S.N., Nakoskina N.V., Shchurova E.N., Popkov A.V. Specific dynamics in vascular endothelial growth factors (VEGF) in blood of patients with vitamin D-resistant rickets during correction of multiplanar deformities of lower limbs. Genij Ortopedii, 2020, vol. 26, no 1, pp. 37-43. DOI 10.18019/1028-4427-2020-26-1-37-43. (In Russian) 
deformity of lower limbs has not been properly studied at different stages of surgical treatment.

Objective Explore blood serum concentration of VEGF and VEGF-A and their receptors VEGF-R2,
VEGF-R3 at stages of combined osteosynthesis in patients with vitamin D-resistant rickets during correction of multiplanar deformities of lower limbs.

\section{MATERIAL AND METHODS}

The study included 24 patients with multiplanar deformities of lower limbs secondary to vitamin D-resistant rickets. The patients' age ranged from 7 to 40 years (mean age $18.6 \pm 2.7$ years). Seven individuals had limb length discrepancy of $2 \mathrm{~cm}$ to $11 \mathrm{~cm}(4.8 \pm 1.2 \mathrm{~cm}$, on average). Patients were treated with combined transosseous mono-, bi-, polyfocal osteosynthesis with the Ilizarov external fixator and intramedullary nailing using hydroxyapatite-coated wires. $1.8 \mathrm{~mm}$ intramedullary wires were introduced through tibial condyles for bone reinforcement. Osteotomy was produced in the upper and lower thirds of tibia and in the distal fibula for deformity correction and limb lengthening. Proximal tibial osteotomy was normally performed below the physis. Three-ring Ilizarov frame was applied to fix the bone with a ring placed above the osteotomy level, another ring being below the osteotomy, at the boundary of the upper and middle thirds, and one more ring mounted in the lower third of tibia. The deformity was corrected by distracting the rods with hinges mounted at the level of the proximal tibial osteotomy and lasted from 20 to 55 days depending on severity and magnitude of the deformity and the length discrepancy. No bone wedges were resected for acute correction.

The study received a favourable opinion from the relevant research ethics committee of the Russian Ilizarov Scientific Centerfor Restorative Traumatology and Orthopaedics Ministry of Health of the Russian Federation. The study was performed in accordance with ethical principles for medical research involving human subjects stated in the Declaration of Helsinki developed by the World Medical Association adopted in 1964 with amendments. Written informed consent was obtained from all patients 18 years and older and from the subject's parents or guardian for diagnostic procedures and publication of the findings without identifying details.

Serum samples were collected preoperatively, at $5-7,30,60,90$ days postsurgery for immunoenzyme investigation to evaluate changes in GF at four stages of treatment: 1) preoperatively, 2) after osteotomy and placement of external fixation device; 3) during bone distraction and regeneration; 4) during fixation and dense callus formation.

Serum concentration of VEGF and VEGF-A and their receptors VEGF-R2, VEGF-R3 were measured during treatment using Thermo Fisher Scientific (USA) products: Multiscan FC, Shaker-401, WellWash Microplate Washer according to manufacturer's instructions to assays eBioscience (VEGF-A, VEGF-R2, VEGF-R3), Invitrogen (VEGF).

The study group consisted of individuals aged 7 to 40 years who had normal emunctory function. Persons experiencing allergic, somatic and neuropsychological disorders, pregnancy, obesity and undernourishment, comorbidities like gastric ulcer, chronic cholecystitis, pancreatitis, chronic obstructive pulmonary disease and infection were excluded from the study. Values obtained in the patients were compared to reference levels measured in 180 somatically healthy individuals. The quantified results were presented in a percentage of the reference values. The controls' age ranged from 7 to 40 years.

Statistical data analysis was performed using Microsoft EXCEL-2010 and AtteStat computer program [19]. Analysis of variance applied for smaller sample size was employed with the level of statistical significance quoted as $\mathrm{p} \leqslant 0.05$. Wilcoxon, Dunn and Mann-Whitney tests were used for independent samples [20].

\section{RESULTS}

Preoperative serum VEGF and VEGF-R2 concentration was significantly higher in patients with vitamin D-resistant rickets (Fig.1) than that in normal subjects: VEGF, by $1990 \%$ ( $\mathrm{p}=0.0033$ ); VEGF-A, by $450 \%(p=0.00042)$; VEGF-R2, by $392 \%(p=0.0052)$ while preoperative serum VEGF-R3 concentration was lower by $68 \%(\mathrm{p}<0.05)$ in the patients than that in subjectively healthy individuals (Fig. 2).

Statistically significant increase in VEGF (41.2 \%) and VEGF-A (43.0 \%) concentration with regard to 
preoperative level that constituted $2811 \%$ and $643 \%$ of normal values, respectively (Fig. 2) was noted with osteotomy performed, wires and external fixation frame placed at the first stage of tretment (Fig. 3).

The opposite dynamics was observed with VEGF-R2 and VEGF-R3 receptors. Preoperative
VEGF-R2 concentration constituted $392 \%$ of normal level and decreased by $41 \%$ postsurgery being $230 \%$ of the values measured in subjectively healthy individuals. Postoperative VEGF-R3 concentration remained at the preoperative level (Fig. 2).
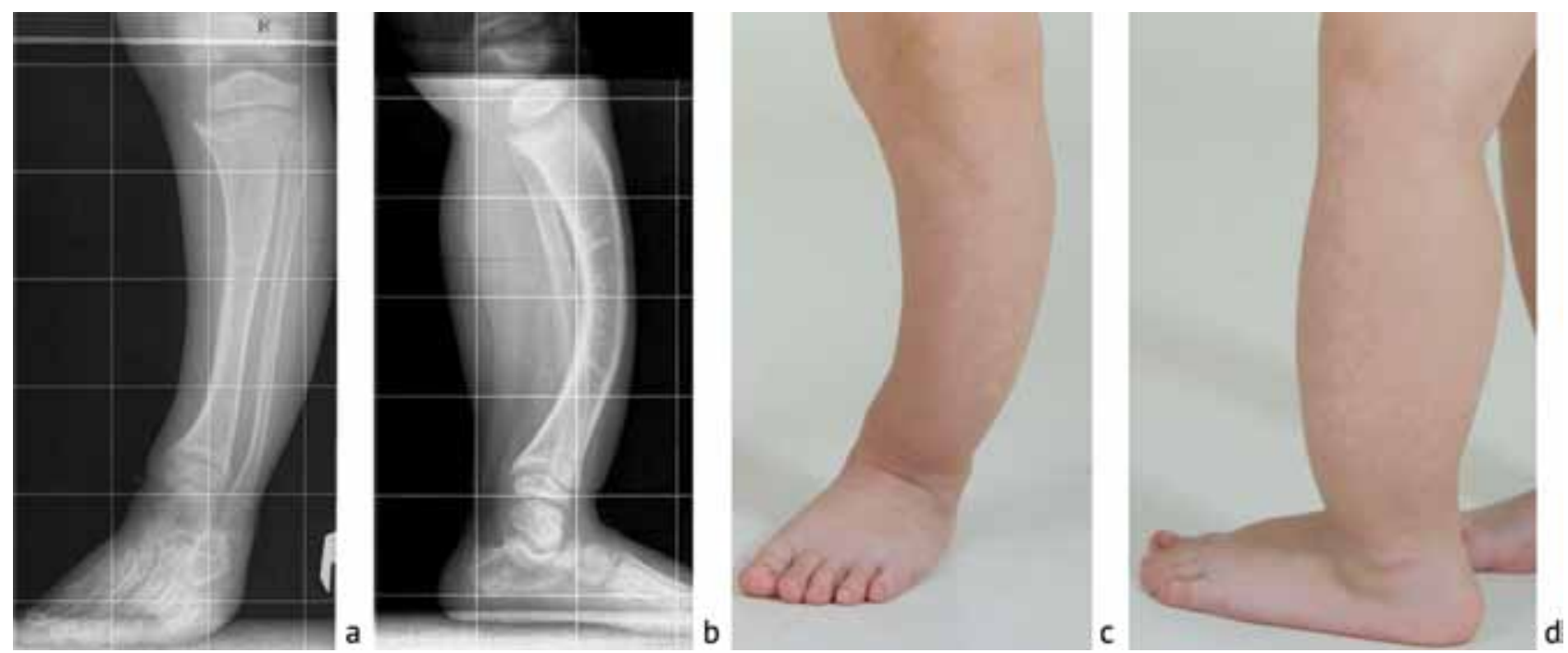

Fig. 1 Preoperative radiographs of the left tibia of a patient with vitamin D-resistant rickets showing: $\boldsymbol{a}$ anteroposterior view, $\boldsymbol{b}$ lateral view; photographs of the lower limb demonstrating $\boldsymbol{c}$ anterior and $\boldsymbol{d}$ lateral aspects

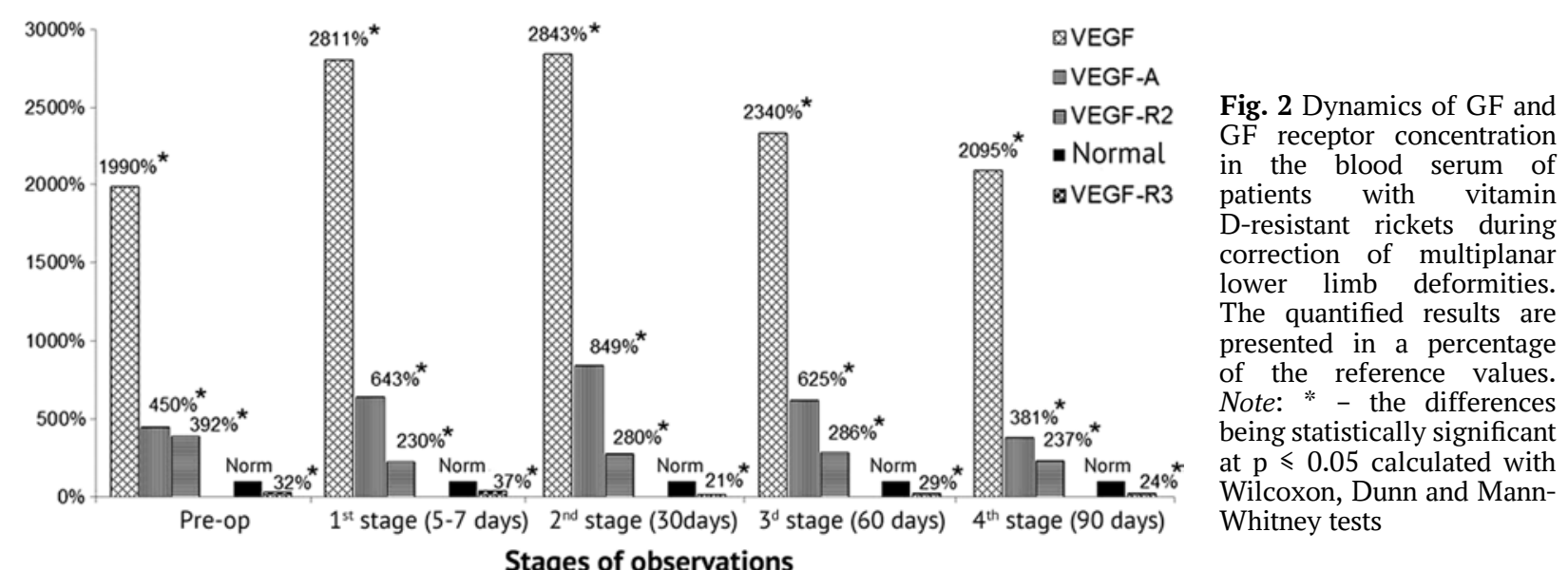

Stages of observations
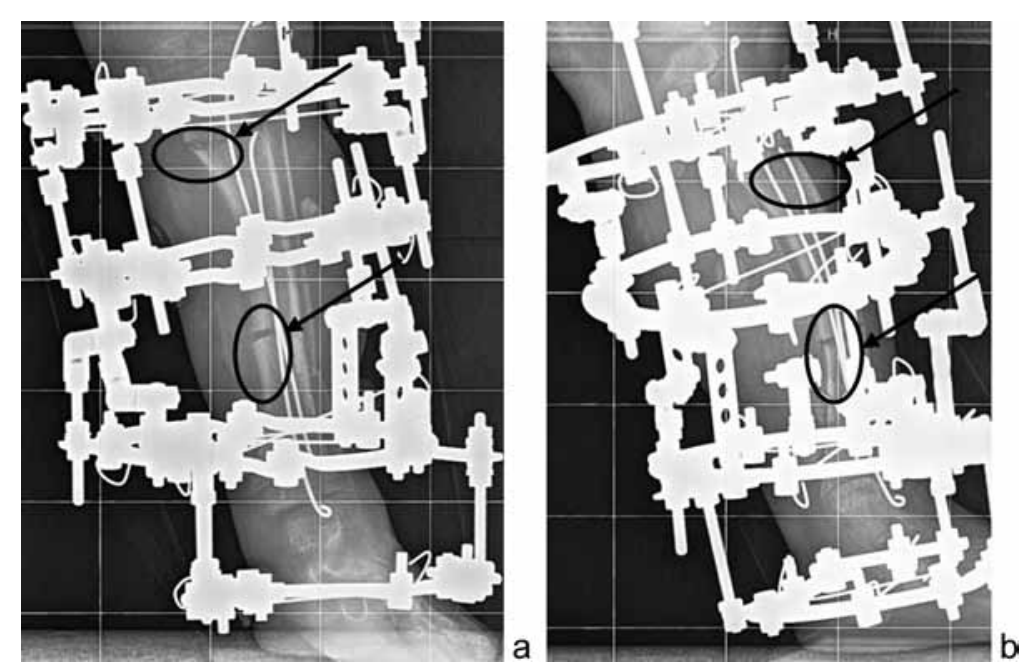

Fig. 3 Anteroposterior $\boldsymbol{a}$ and lateral $\boldsymbol{b}$ radiographs of the tibia of a patient with vitamin D-resistant rickets showing tibial osteotomy (black arrows) performed and external fixation device applied 
Maximal VEGF and VEGF-A concentrations (Fig. 2) measured $2843 \%$ and $849 \%$ of normal values, respectively, at the second stage of treatment with the regenerate bone (Fig. 4) developed due to distraction using external fixation device.

VEGF-R2 concentration was shown to increase by $22 \%$ compared to that measured at the first stage of treatment but it was still decreased by $29 \%$ as compared to the baseline level. VEGF-R3 concentration was considerably reduced as compared to the first stage (by $43 \%$ ) and baseline level (by $34 \%$ ) and constituted $21 \%$ of the normal value (Fig. 2). An increase of $18 \%$ and $39 \%$ was observed in VEGF and VEGF-A concentrations at the third stage of tibial fixation and dense callus formation (60 days postsurgery) as compared to baseline values. Serum VEGF-R2 level was identical to that measured at the second stage of treatment and decreased by $27 \%$ as compared to the baseline concentration. VEGF-R3 concentration returned to the baseline level and was $29 \%$ of the normal value. No statistically significant differences were observed in VEGF and VEGF-A concentrations at the fourth stage of treatment (Fig. 5) as compared to the baseline level.

Concentration of VEGF-R2 receptor was reduced by $39 \%$ as compared to the baseline level and was identical to that measured at the second stage of treatment. VEGF-R3 concentration was reduced by $25 \%$ as compared to the baseline level measuring $24 \%$ of the normal value and was also identical to that recorded at the second stage of treatment.

Thus, patients with vitamin D-resistant rickets showed considerable disproportion in the serum concentrations of VEGF and VEGF receptors. Preoperative serum concentrations of VEGF, VEGF-A and VEGF-R2 receptor were considerably higher than normal levels and VEGF-R3 receptor concentration was significantly lower than that in subjectively healthy individuals.
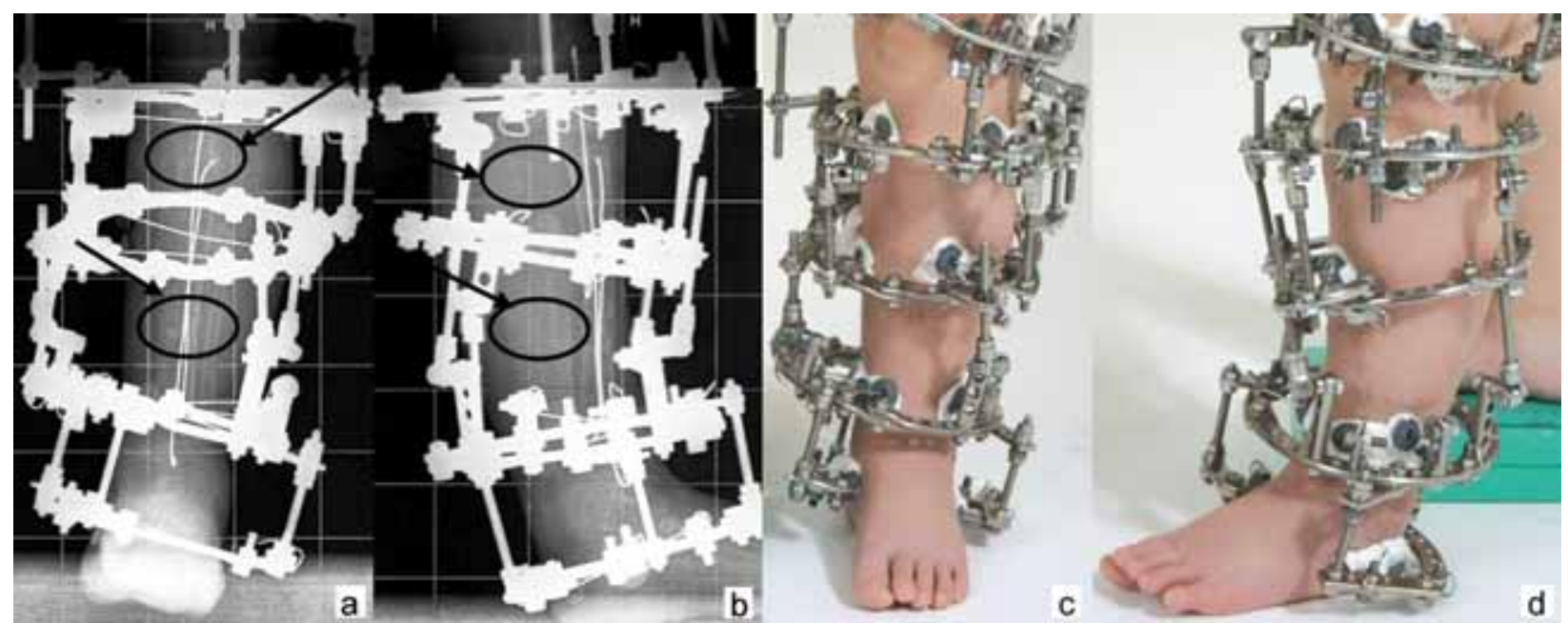

Fig. 4 Radiographs of the left tibia of a patient with vitamin D-resistant rickets showing tibial distraction on $\boldsymbol{a}$ anteroposterior view, $\boldsymbol{b}$ lateral view; photographs of the lower limb demonstrating $\boldsymbol{c}$ anterior and $\boldsymbol{d}$ lateral aspects. Arrows show tibial osteotomies
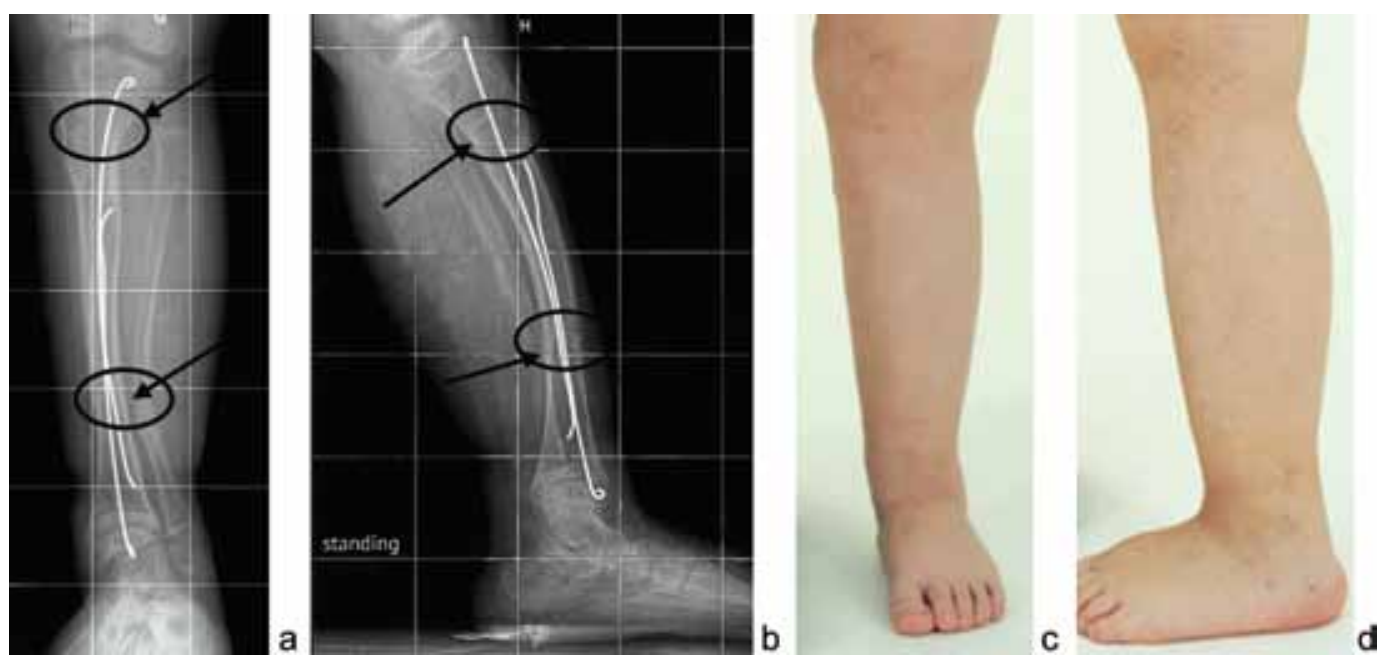

Fig. 5 Radiographs of the left tibia of a patient with vitamin D-resistant rickets showing $\boldsymbol{a}$ anteroposterior view, $\boldsymbol{b}$ lateral view; photographs of the lower limb demonstrating $\boldsymbol{c}$ anterior and $\boldsymbol{d}$ lateral aspects directly after the treatment. Arrows show tibial osteotomies 
The disproportions in GF and GF receptor secretion were noted to enhance during surgical correction of multiplanar lower limb deformities. VEGF and VEGF-A concentrations were considerably increased during surgical correction, tibial distraction and regenerate formation at the second stage, in particular, and returned to the baseline level at the next stage of treatment. The opposite dynamics was observed with VEGF-R2 receptor showing serum decreased concentration at the first stage of treatment that increased at the second stage and was still low compared to baseline values. The scenario persisted throughout the whole period of treatment.
Specific dynamics was noted with VEGF-R3 receptor during surgical correction. Nearly preoperative serum concentration of VEGF-R3 was seen at the first stage showing the lowest level (21\% of the normal) during bone distraction with external fixator and regenerate formation being close to baseline values at the third stage. It was reduced by $25 \%$ of the preoperative level at the end of treatment. Dynamics in VEGF-R2 and VEGF-R3 receptor concentrations was characterized by inversely proportional reactions and delayed restorative processes during surgical correction of limb deformities.

\section{DISCUSSION}

VEGF is one of the most important GF for reparative regeneration playing the roles in physiological angiogenesis, promotion of bone formation in ontogenesis and transformation of cartilage to bone (enchondral ossification) during distractional bone regeneration [13-18]. VEGF as a heterodimeric and glycoprotein GF is reponsible for revascularization and angiogenesis of bone callus during enchondral ossification and is expressed by osteoblasts [21, 22]. VEGF is involved in many steps throughout the fracture healing cascade [23], and being a selective endothelial cell mitogen can induce vascular permeability. Higher serum VEGF levels are reported to result in increased secretion of the GF [24, 25]. Hypoproteinemia is a common condition in vitamin D-resistant rickets, associated with decreased serum alkaline level and leads to the development of acidosis [26]. Acidosis results in impaired microcirculation and depresses the central nervous system and internal organs. Osteogenesis is disturbed by impaired calcium, citrate and phosphorus metabolism, deficiency of active metabolite vitamin D regulating hydroxyapatite deposition in bones. Higher calcium excretion is associated with lower bone mineral density, a predictor of osteoporosis, delayed bone calcification and abnormal cartilage resorption. Cartilaginous and osteoid cells proliferate chaotically in the physes. Osteoid hyperplasia can be seen in the epiphyses of tubular bone and growth points. Longitudinal bone growth is delayed resulting in hypoplastic bone [26]. Isolated mechanical stretching in cell culture being similar to that generated by external fixation device during distraction at limb lengthening and/or deformity correction has been shown to induce VEGF secretion. Exercise-induced increases in blood flow, shear stress and endothelial transformation are observed to enhance VEGF concentrations [27]. Therefore, hypoxia is a functionally relevant stimulus for VEGF gene expression. Recent studies indicate to increased intracellular concentrations in hypoxia-inducible transcription factor (HIF)-1 alpha, an essential regulator of the cellular response to reduced oxygen levels, in the retina of healthy individuals. Increased intracellular HIF-1 level enhances transcription of VEGF gene effecting the epithelium through intercelullar matrix, contributes to regeneration and stimulates proliferation and formation of new vessels [28]. Hyperplastic osteoid tissue affects VEGF synthesis with higher osteoblast concentration, and the combination of the factors results in several-fold increase of VEGF and VEGF-A level as compared to that observed in healthy individuals but without proportinal receptor increase due to pathology.

It can be concluded that a diverse array of pathological consequences in vitamin D-resistant rickets is not limited to impaired bone quality, delayed remodeling and calcification but associated with evident quantitative changes in VEGF. The specific aspect identified can affect concomitant pathological processes and play a role in developing a rational treatment strategy.

\section{CONCLUSION}

Patients with vitamin D-resistant rickets concentrations of VEGFs and their receptors. demonstrated strong imbalance in serum Preoperative serum VEGF, VEGF-A and VEGF-R2 
concentrations were significantly higher in patients with vitamin D-resistant rickets than that in normal subjects while preoperative serum VEGF-R3 concentration was significantly lower in the patients than that in subjectively healthy individuals. Greater imbalance in serum concentrations of VEGFs and their receptors was identified during correction of multiplanar lower limb deformities. Surgical treatment of patients with vitamin D-resistant rickets including tibial osteotomy and distractional bone regeneration resulted in greater increase in VEGF and VEGF-A levels. Dynamics in VEGF-R2 and VEGF-R3 receptor concentrations was characterized by inversely proportional reactions and delayed restorative processes during surgical correction of limb deformities.

\section{REFERENCES}

1. Bochkov N., Asanov A., Zhuchenko N., Subbotina T., Filippova M., Filippova M. Meditsinskaia Genetika: ucheb. [Medical genetics: manual]. M., GEOTAR-Media, 2014, pp. 43-45. (in Russian)

2. Balsan S., Tieder M. Linear growth in patients with hypophosphatemic vitamin D-resistant rickets: influence of treatment regimen and parental height. J. Pediatr., 1990, vol. 116, no. 3, pp. 365-371.

3. Nield L.S., Mahajan P., Joshi A., Kamat D. Rickets: not a disease of the past. Am. Fam. Physician, 2006, vol. 74, no. 4, pp. $619-626$.

4. Stogov M.V., Luneva S.N., Tkachuk E.A. Biokhimicheskie pokazateli v prognozirovanii techeniia osteoreparativnykh protsessov pri travme kostei skeletal [Biochemical values in predicting the course of osteoreparative processes in case of skeletal bone injury]. Klinicheskaia Laboratornaia Diagnostika, 2010, no. 12, pp. 5. (in Russian)

5. Leviashvili Zh.G., Savenkova N.D., Musaeva A.V., Belov D.Iu. Pokazateli neorganicheskogo fosfata, paratireoidnogo gormona krovi i pochechnoi kanaltsevoi reabsorbtsii fosfatov u detei s nasledstvennym gipofosfatemicheskim rakhitom [The values of inorganic phosphate, blood parathyroid hormone and renal tubular reabsorption in children with hereditary hypophosphatemic rickets]. Nefrologiia, 2014, vol. 18, no. 3, pp. 45-56. (in Russian)

6. Novikov P.V. Rakhit i nasledstvennye rakhitopodobnye zabolevaniia u detei: diagnostika, lechenie, profilaktika [Rickets and hereditary rickets-like diseases in children: diagnosis, treatment, prevention]. M., Triada-Kh, 2006, 336 p. (in Russian)

7. Diachkova G.V., Riazanova E.A., Diachkov K.A., Korabelnikov M.A. MRT i KT vizualizatsiia posledstvii rakhita i vitamin d-rezistentnogo rakhita [MRT- and CT-visualization of the sequelae of rickets and vitamin D-resistant rickets]. Genij Ortopedii, 2008, no. 1, pp. 33-36. (in Russian)

8. Popkov A.V., Popkov D.A., Gorbach E.N., Korkin A.Ia. Problemy operativnogo lecheniia detei, stradaiushchikh vitamin d-rezistentnym rakhitom [The problems of surgical treatment of children with vitamin-D-resistant rickets]. Genij Ortopedii, 2014, no. 2, pp. 39-43. (in Russian)

9. Vernakova S.S., Gladkaia Ia.I. Analiz kachestva profilaktiki rakhita u detei po materialam detskoi polikliniki № 1 g. Tiumeni [The analysis of rickets prevention quality in children by the materials of Tiumen Children Polyclinic No 1]. Materialy Vseros. Nauch. Konf. molodykh uchenykh "Aktualnye problemy teoreticheskoi, eksperimentalnoi i klinicheskoi meditsiny" [Materials of the AllRussian Scientific Conference of young scientists “Actual Problems of Theoretical, Experimental and Clinical Medicine”]. Tiumen, 2002, pp. 132-133. (in Russian)

10.Skliar L.V., Murzikov N.M., Korkin A.Ia. Vybor metodiki operativnogo ustraneniia o-obraznykh deformatsii nizhnikh konechnostei $\mathrm{u}$ detei i podrostkov [Selection of the technique for surgical elimination of O-shaped deformities of the lower limbs in children and adolescents]. Materialy nauch. konf. "Sovremennye Aspekty Chreskostnogo Osteosinteza po Ilizarovu" [Materials of scientific conference "Modern Aspects of Transosseous Osteosynthesis according to Ilizarov"]. Kazan, 1991, pp. 42-43. (in Russian)

11. Shevtsov V.I., Popkov A.V. Operativnoe udlinenie nizhnikh konechnostei [Surgical Lengthening of the Lower Limbs]. M., Meditsina, 1998, 189 p. (in Russian)

12.Sertakova A.V., Norkin I.A., Rubashkin S.A. Biomarkery remodelirovaniia kostnoi tkani i rostovye faktory rosta $v$ diagnostike stadii osteonekroza golovki bedra u detei [Biomarkers of bone tissue remodeling and growth factors in diagnosing the stages of femoral head osteonecrosis in children]. Molekuliarnaia Meditsina, 2014, no. 6, pp. 25-29. (in Russian)

13.Shimer A.L., Oner F.C., Vaccaro A.R. Spinal reconstruction and bone morphogenetic proteins: open questions. Injury, 2009, vol. 40, no. Suppl. 3, pp. S32-S38. DOI: 10.1016/S0020-1383(09)70009-9.

14.Ulianina E.V., Fatkullin I.F., Khairullina G.R. Markery angiogeneza i ultrazvukovogo issledovaniia v otsenke stepeni tiazhesti sindroma zaderzhki razvitiia ploda [The markers of angiogenesis and ultrasound investigation in evaluating the severity of fetal growth retardation syndrome]. Vestnik Sovremennoi Klinicheskoi Meditsiny, 2016, vol. 9, no. 5, pp. 79-82. (in Russian) DOI: 10.20969/VSKM.2016.9(5).79-82.

15.Vecchiarelli-Federico L.M., Cervi D., Haeri M., Li Y., Nagy A., Ben-David Y. Vascular endothelial growth factor - a positive and negative regulator of tumor growth. Cancer Res., 2010, vol. 70, no. 3, pp. 863-867. DOI: 10.1158/0008-5472.CAN-09-3592.

16.Witsch E., Sela M., Yarden Y. Roles for growth factors in cancer progression. Physiology (Bethesda), 2010, vol. 25, no. 2, pp. 85101. DOI: 10.1152/physiol.00045.2009.

17.Haigh J.J., Gerber H.P., Ferrara N., Wagner E.F. Conditional inactivation of VEGF-A in areas of collagen2a1 expression results in embryonic lethality in the heterozygous state. Development, 2000, vol. 127, no. 7, pp. 1445-1453.

18.Stogov M.V., Luneva S.N., Novikov K.I. Growth factors in human serum during operative tibial lengthening with the Ilizarov method. J. Orthop. Res., 2013, vol. 31, no. 12, pp.1966-1970. DOI: 10.1002/jor.22454.

19.Gaidyshev I.P. Analiz i obrabotka dannykh: spets. spravochnik [Data analysis and processing: special manual]. SPb., Piter, 2001, 145 p. (in Russian)

20.Glantz S. Primer of Biostatistics. $4^{\text {th }}$ Ed. McGraw-Hill Publishing Company, 1997. (Russ. ed.: Glantz S. Mediko-biologicheskaia Statistika. M., Praktika, 1998, 459 p.) 
21.Nahar N.N., Missana L.R., Garimella R., Tague S.E., Anderson H.C. Matrix vesicles are carriers of bone morphogenetic proteins (BMPs), vascular endothelial growth factor (VEGF), and noncollagenous matrix proteins. J. Bone Miner. Metab., 2008, vol. 26, no. 5, pp. 514-519. DOI: 10.1007/s00774-008-0859-z.

22.Yang Y.Q., Tan Y.Y., Wong R., Wenden A., Zhang L.K., Rabie A.B. The role of vascular endothelial growth factor in ossification. Int. J. Oral Sci., 2012, vol. 4, no. 2, pp. 64-68. DOI:10.1038/ijos.2012.33.

23.Simpson A.H., Mills L., Noble B. The role of growth factors and related agents in accelerating fracture healing. J. Bone Joint Surg. Br., 2006, vol. 88, no. 6, pp. 701-705. DOI: 10.1302/0301-620X.88B6.17524.

24.Shurygin M.G., Shurygina I.A., Dremina N.N. Dinamika faktorov rosta endoteliia sosudov i fibroblasticheskogo faktora rosta pri eksperimentalnom infarkte miokarda [The dynamics of vascular endothelium growth factors and fibroblastic growth factor for experimental myocardial infarction]. Acta Biomedica Scientifica, 2007, no. 6, pp. 169-174. (in Russian)

25.Bershova T.V., Bakanov M.I., Smirnov I.E., Sanfirova V.M., Korneeva I.T., Poliakov S.D., Soloveva Iu.V. Izmeneniia funktsionalnogo sostoianiia sosudistogo endoteliia u iunykh sportsmenov razlichnoi kvalifikatsii [Changes in vascular endothelium functional state in young athletes of various qualifications]. Rossiiskii Pediatricheskii Zhurnal, 2016, vol. 19, no. 1, pp. 14-19. (in Russian) DOI: 10.18821/1560-9561-2016-19(1)-14-19.

26.Maidannik V.G. Pediatriia: ucheb. dlia stud. vyssh. med. ucheb. zavedenii III-IV urovnei akkreditatsii [Pediatry: textbook for students of higher medical educational institutions of III-IV accreditation levels]. Kharkov, Folio, 2002, 1125 p. (in Russian)

27.Mac Gabhann F., Qutub A.A., Annex B.H., Popel A.S. Systems biology of pro-angiogenic therapies targeting the VEGF system. Wiley Interdiscip. Rev. Syst. Biol. Med., 2010, vol. 2, no. 6, pp. 694-707. DOI: 10.1002/wsbm.92.

28.Kuzmin A.G., Lipatov D.V., Smirnova O.M., Shestakova M.V. Anti-VEGF preparaty dlia lecheniia diabeticheskoi retinopatii [AntiVEGF preparations for diabetic retinopathy treatment]. Oftalmokhirurgiia, 2009, no. 3, pp. 53-57. (in Russian)

Received: 21.09.2018

\section{Information about the authors:}

1. Nikita S. Gvozdev,

National Ilizarov Medical Research Centre for Orthopaedics and Traumatology, Kurgan, Russian Federation

2. Evgeniia P. Vykhovanets,

National Ilizarov Medical Research Centre for Orthopaedics and Traumatology, Kurgan, Russian Federation

3. Svetlana N. Luneva, Ph.D. of Biological Sciences, Professor,

National Ilizarov Medical Research Centre for Orthopaedics and Traumatology, Kurgan, Russian Federation,

Email: luneva_s@mail.ru

4. Natalia V. Nakoskina,

National Ilizarov Medical Research Centre for Orthopaedics and Traumatology, Kurgan, Russian Federation

5. Elena N. Shchurova, Ph.D. of Biological Sciences,

National Ilizarov Medical Research Centre for Orthopaedics and Traumatology, Kurgan, Russian Federation

6. Arnold V. Popkov, M.D., Ph.D., Professor,

National Ilizarov Medical Research Centre for Orthopaedics and Traumatology, Kurgan, Russian Federation,

Email: apopkov.46@mail.ru 